\title{
Woody Species Diversity in Traditional Agroforestry Practices of Dellomenna District, Southeastern Ethiopia: Implication for Maintaining Native Woody Species
}

\author{
Abiot Molla ${ }^{1}$ and Gonfa Kewessa ${ }^{2}$ \\ ${ }^{1}$ Department of Natural Resource Management, Debre Markos University, 251269 Debre Markos, Ethiopia \\ ${ }^{2}$ Department of Forestry, Madda Walabu University, 251247 Bale Robe, Ethiopia \\ Correspondence should be addressed to Abiot Molla; abiotmolla6@gmail.com
}

Received 23 September 2015; Revised 2 November 2015; Accepted 3 November 2015

Academic Editor: Alexandre Sebbenn

Copyright (C) 2015 A. Molla and G. Kewessa. This is an open access article distributed under the Creative Commons Attribution License, which permits unrestricted use, distribution, and reproduction in any medium, provided the original work is properly cited.

\begin{abstract}
The major impact of humans on forest ecosystems including loss of forest area, habitat fragmentation, and soil degradation leads to losses of biodiversity. These problems can be addressed by integration of agriculture with forests and maintaining the existing forests. This study was initiated to assess woody species diversity of traditional agroforestry practices. Three study sites (Burkitu, Chire, and Erba) were selected based on the presence of agroforestry practice. Forty-eight (48) sample quadrants having an area of $20 \mathrm{~m} \times 20 \mathrm{~m}, 16$ sample quadrants in each study site, were systematically laid using four transect lines at different distance. The diversity of woody species was analyzed by using different diversity indices. A total of 55 woody species belonging to 31 families were identified and documented. There were significantly different $(P<0.05)$ among the study Kebeles (peasant associations). Mangifera indica, Entada abyssinica, and Croton macrostachyus were found to have the highest Important Value Index. The results confirmed that traditional agroforestry plays a major role in the conservation of native woody species. However, threats to woody species were observed. Therefore, there is a need to undertake conservation practices before the loss of species.
\end{abstract}

\section{Introduction}

Agriculture is the main backbone of the economy but also the major occupation of Ethiopian population [1]. Rapid population growth and long history of sedentary agriculture have changed the land use/land cover systems and caused environmental degradation in many developing countries including Ethiopia [2]. Bishaw and Asfaw [3] indicated that population growth and environmental degradation on forest ecosystems lead to loss of forest area, habitat fragmentation, soil degradation, and biodiversity losses. International concern is to find alternative farming systems that are ecologically and economically sustainable as well as culturally acceptable to local communities.

Agroforestry is a dynamic ecologically based natural resources management system through integration of trees on farms that diversifies agricultural landscapes and sustains production for increased social, economic, and environmental benefits [4]. Agroforestry systems are known to bring about changes in edaphic, microclimatic, floral, faunal, and other components of the ecosystem through biorecycling of mineral elements, environmental modifications, and changes in floral and faunal composition [5-7]. According to Schroth et al. [8], agroforestry also contributes to biodiversity conservation on a landscape scale in three ways. These are (i) the provision of supplementary secondary habitat for species that tolerate a certain level of disturbance, (ii) the reduction rates of conversion of natural habitat in certain cases, and (iii) the creation of a more benign and permeable "matrix" between habitat remnants compared with less tree-dominated land uses, which may support the integrity of these remnants and the conservation of their populations.

There are several types of traditional agroforestry practices in different parts of Ethiopia. Some of the different 
agroforestry practices include coffee shade tree systems, scattered trees on the farm land, home gardens, woodlots, farm boundary practices, and trees on grazing lands $[9,10]$. Adjoining habitats that are more similar to the remnants in terms of structure and floristic composition are the most beneficial to the long-term preservation of biodiversity [8]. In addition to supporting native species of plants and animals, agroforestry areas may contribute to the conservation of biodiversity by increasing the connectivity of populations, communities, and ecological processes in fragmented landscapes [11].

Agroforestry systems may maintain considerable intraspecific genetic variation at the landscape level, and this variation is essential for adaptation to changes in environmental conditions [12]. Agroforestry systems serve as in situ conservation areas for many species that farmers value and therefore wish to conserve [13]. The mechanisms by which traditional agroforestry systems contribute to biodiversity have been examined by various authors $[8,14-$ 16]. The same authors indicated that agroforestry plays five major roles in conserving biodiversity: (1) provides habitat for species that can tolerate a certain level of disturbance; (2) helps to preserve germ-plasm of sensitive species; (3) helps to reduce the rates of conversion of natural habitat by providing a more productive, sustainable alternative to traditional agricultural systems that may involve clearing natural habitats; (4) provides connectivity by creating corridors between habitat remnants which may support the integrity of these remnants and the conservation of area-sensitive floral and faunal species; and (5) helps to conserve biological diversity by providing other ecosystem services such as erosion control and water recharge, thereby preventing the degradation and loss of surrounding habitat. Agroforestry practices are the main option to reduce these problems. In the study area (Dellomenna District), farmers have been practicing different traditional agroforestry practices by integrating different woody perennials, crops, and livestock components in their lands. These traditional agroforestry practices constitute perennial and herbaceous plants that may promote biodiversity conservation and socioeconomic alternatives to local communities. However, the contribution of these traditional agroforestry practices on biodiversity conservation has not been studied so far in Dellomenna District. Therefore, this study was initiated to investigate status of woody species diversity in traditional agroforestry practices of Dellomenna District with particular emphasis on maintaining native woody species.

\section{Materials and Methods}

\subsection{The Study Area}

Location. Dellomenna District is one of the districts found in Bale Zone, Southeast Ethiopia. Geographically, it lies between $6^{\circ} 40^{\prime}-7^{\circ} 10^{\prime} \mathrm{N}$ and $39^{\circ} 30^{\prime}-40^{\circ} \mathrm{E}$ (Figure 1). The district comprises 14 Kebeles with a total area of 461,665 hectares. It is bordered in the west by Harenna-Buluk District, in the east by Berbere and Guradamole Districts, in the North by Goba District, and in the South by Madda Walabu District [17].

Topography and Climate. The area is characterized by flat lands and moderately steep rolling hills with valley bottoms. The altitude of the district ranges within 1000-2500 meters above sea level. It has two agroclimatic zones where $86.7 \%$ is "Kolla" (dry, hot tropical climate) while the remaining $13.3 \%$ is "Woina Dega" (moist to humid, warm subtropical climate). The rainfall pattern in the area is the bimodal type, that is, middle of March to end of May (short rain season) and September to October (the main rainy season). Annual rainfall ranges within $700-1200 \mathrm{~mm}$. The average temperature for Dellomenna is $18^{\circ} \mathrm{C}$ [17].

Population and Means of Livelihood. The total population of Dellomenna District is 96,161 with a population density of 21 persons $/ \mathrm{km}^{2}$ [18]. There are various sources of livelihood and income for local communities living in the district. These include Coffee arabica, honey, Catha edulis, crops, livestock production, timber, and other nontimber forest products. These products serve either for household consumption or for cash income or both. For example, honey, Catha edulis, and coffee are exclusively for income and field crops and livestock are mainly for household consumption.

Land Use. The land use categories of this district are forest, agriculture, grazing land, and settlement [17]. According to Tadesse and Feyera [18], natural forest and woodlands still account for the largest share of the land use types in the district. Despite its large coverage, natural forest in Dellomenna District is under pressure by humans. Agricultural expansion, settlement, overgrazing, forest fire, and intensive management of coffee in the forest are the major threats to the natural forest. Tef (Eragrostis tef (Zucc.) Trotter), maize (Zea mays), sorghum (Sorghum bicolor L.), and haricot bean are the major field crops grown in the district. Fruits like mango (Mangifera indica), banana (Musa species), papaya (Carica papaya), avocado, Annona muricata, and Psidium guajava are common in the area. Vegetables including cabbage, carrot, pepper, onion, Irish potato, and sweet potato (Ipomoea batatas) are also grown in the area [18]. Various types of traditional agroforestry practices are also observed in the area. These include home garden and multipurpose trees on the farm land and farm boundary, agrosilvopastoral and silvopastoral [19].

\subsection{Data Collection Methods}

2.2.1. Sampling Techniques. Systematic sampling methods were employed during the course of this study. The sampling procedures focused on identification of areas having traditional agroforestry practices. Accordingly three study sites were selected: Burkitu, Chire, and Erba Kebele were selected. Finally, based on the topography or the gradient land 

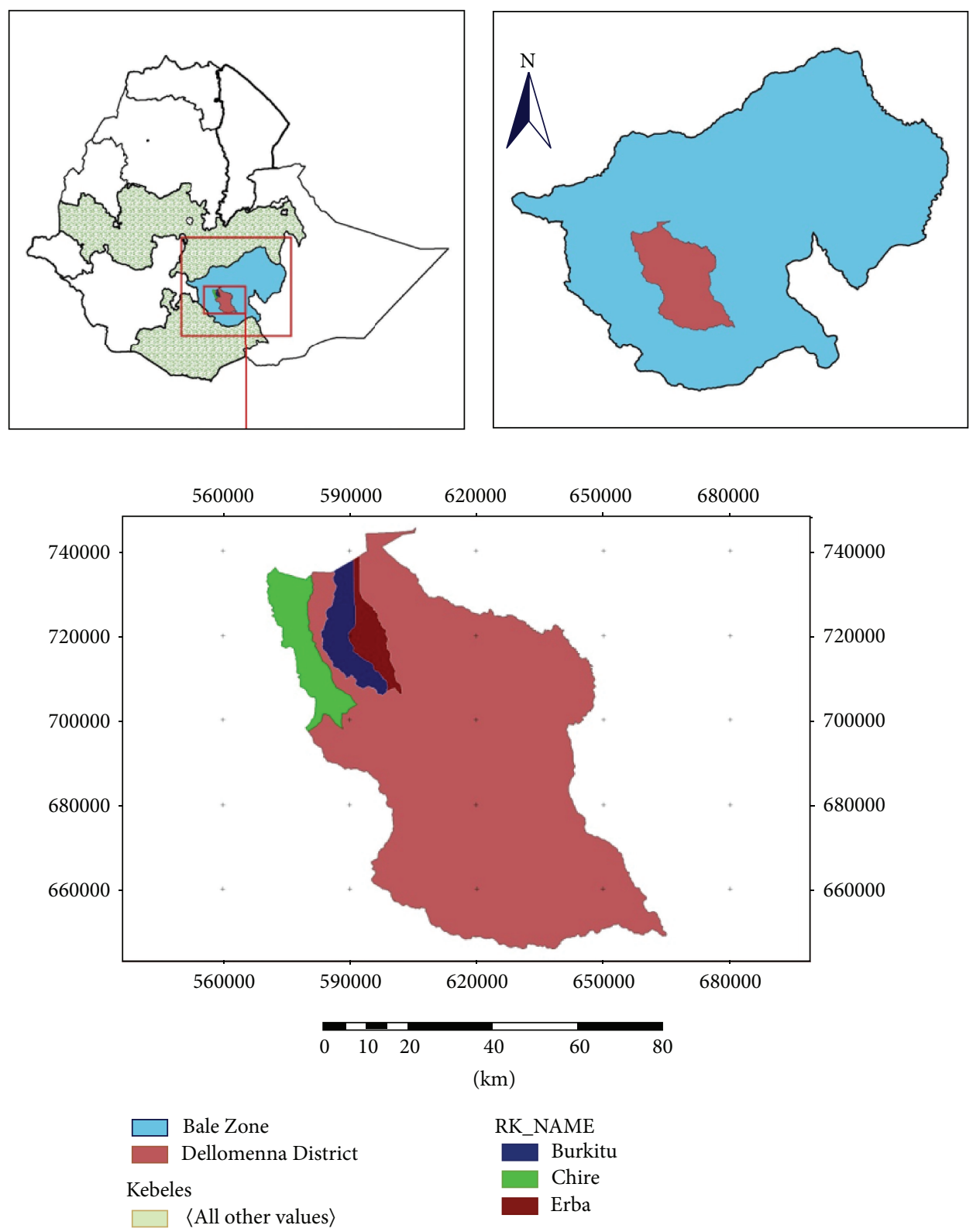

Figure 1: Map of the study sites in Dellomenna District, Southeastern Ethiopia.

use systems, four transect lines were aligned at an interval of $500 \mathrm{~m}$ in each selected Kebele. On each transect, four quadrats were laid at an interval of $200 \mathrm{~m}$. The first transect line and the first plot were systematically selected.

A total of 48 quadrats, 16 quadrats in each selected Kebele, were used for vegetation assessment.

Samples of all tree and shrub species encountered during this assessment were collected and recorded in their local names and later converted into scientific name by researchers themselves and by the use of agroforestry database: tree species reference and selection [20], useful trees and shrubs of Ethiopia [21, 22] and Flora of Ethiopia and Eritrea, Edwards et al. [23], Hedberg et al. [24], and Hedberg et al. [25]. For identification of the trees and shrubs that were not identified by researchers and by use of reference materials, expert field identification was made.

2.2.2. Sampling Design. For the assessment of the diversity of woody species in traditional agroforestry practices, all woody species were recorded, and diameters at breast height $(\mathrm{DBH}$, $1.3 \mathrm{~m}$ ) for all woody species $\geq 5 \mathrm{~cm}$ were measured using a caliper or diameter tape except for coffee [26]. The diameter of coffee shrub was measured at $15 \mathrm{~cm}$ aboveground [27]. A quadrat size of $20 \times 20 \mathrm{~m}\left(400 \mathrm{~m}^{2}\right)$ was used for woody species assessment for diameter $\geq 5 \mathrm{~cm}$ [28]. Within this plot five subplots of $5 \times 5 \mathrm{~m}$, at four corners and in the center, were 
laid for sapling assessment for diameter of $1-5 \mathrm{~cm}$. Within each subplot, again a small five plot of $2 \times 2 \mathrm{~m}$ was laid in each corner and center for seedling assessment for diameter $<1 \mathrm{~cm}$ [28]. The dimensions of the quadrats and sampling size coincide with recommended practice in the ecological literature and represent a compromise between recommended practice, accuracy, and practical considerations of time, resources, and effort [28].

\subsection{Data Analysis}

2.3.1. Woody Species Diversity Indices. Woody species diversity was analyzed by using different diversity indices. Shannon diversity index $\left(H^{\prime}\right)$, Shannon equitability/evenness index $(E)$, species richness $(S)$, and Simpson diversity index (D) were calculated and analyzed. These diversity indices provided important information about rarity and commonness of species in a community. Species richness is the total number of species in the community [29]. It is the oldest and the simplest concept of species diversity.

2.3.2. Shannon-Wiener Diversity Index $\left(H^{\prime}\right)$. Shannon's index accounts for both abundance and evenness of the species present. Two components of diversity are combined in the Shannon diversity index: (1) the number of species and (2) equitability or evenness portion of individuals among the species $[29,30]$. The Shannon diversity index $\left(H^{\prime}\right)$ is high when the relative abundance of the different species in the sample is even and is low when few species are more abundant. It is based on the theory that when there is a large number of species with even proportions, the uncertainty that a randomly selected individual belongs to a certain species increases and thus diversity increases. It relates proportional weight of the number of individuals per species to the total number of individuals for all species [31]. The Shannon diversity index is calculated as follows:

$$
H^{\prime}=-\sum_{i=1}^{S} p_{i} \ln p_{i}
$$

where $H^{\prime}$ is Shannon diversity index and $p_{i}$ is proportion of individuals found in the $i$ th species.

Value of the index $\left(H^{\prime}\right)$ usually lies between 1.5 and 3.5, although, in exceptional cases, the value can exceed 4.5 [31]. The larger the $H^{\prime}$ value, the higher the diversity.

Evenness (Shannon equitability) index $(E)$ was calculated as described by Kent and Coker [31] to estimate the homogeneous distribution of tree species on farms:

$$
E=\frac{H^{1}}{H_{\max }}=\frac{H^{1}}{\ln S}=\frac{\sum_{i=1}^{S} p_{i} \ln p_{i}}{\ln S} \quad \text { with } H_{\max }==\ln S,
$$

where $S$ is the number of species and $p_{i}$ is proportion of individuals of the $i$ th species or the proportion of the total species. $E$ has values between 0 and 1 , with 1 being complete evenness [31]. Usually, Shannon diversity index places most weight on the rare species in the sample [29] and hence Simpson's diversity $(D)$ was used to include the most abundant species.

2.3.3. Simpson's Diversity Index (D). Simpson's diversity index is derived from a probability theory and it is the probability of picking two different species at random $[29,30$, 32]. Simpson's diversity $(D)$ is calculated as

$$
D=1-\sum p_{i}^{2}
$$

where $D$ is Simpson's diversity index and $p_{i}$ is proportion of individuals found in the $i$ th species.

Simpson's diversity index gives relatively little weight to the rare species and more weight to the most abundant species. It ranges in value from 0 (low diversity) to a maximum of $(1-1 / S)$, where $S$ is the number of species $[29,30]$. The above indices, which are generally referred to as alpha diversity, indicate richness and evenness of species within a locality, but they do not indicate the identity of the species where it occurs. Hence, variation in composition of woody species among the different land use types (patch forests and agroforestry) was determined by computing Beta diversity. Beta diversity $(\beta)$ is usually expressed in terms of a similarity index between different habitats in the same geographical area [32].

2.3.4. Similarity Indices $\left(S_{s}\right)$. Similarity indices measure the degree to which the species compositions of different system are alike. Many measures exist for the assessment of similarity or dissimilarity between vegetation samples or quadrats. The Sorensen similarity coefficient is applied to qualitative data and is widely used because it gives more weight to the species that are common to the samples rather than to those that only occur in either sample [31].

The Sorensen coefficient of similarity $\left(S_{s}\right)$ is given by the following formula:

$$
S_{s}=\frac{2 a}{2 a+b+c}
$$

where $S_{s}$ is Sorensen similarity coefficient, $a$ is number of species common to both samples, $b$ is number of species distinctive in sample 1 , and $c$ is number of species distinctive in sample 2 .

2.3.5. Important Value Index. The Important Value Index (IVI) is a composite index based on the relative measures of species frequency, abundance, and dominance [31]. It indicates the significance of species in the system. It is calculated as follows:

$$
\begin{aligned}
& \text { IVI (\%) } \\
& =\text { Relative abundance }+ \text { Relative dominance } \\
& + \text { Relative frequency, }
\end{aligned}
$$


Relative abundance

$$
\begin{aligned}
= & \frac{\text { Number of individual } s \text { of woody species }}{\text { Total number of woody individual } s} \\
& * 100
\end{aligned}
$$

Relative dominance

$$
=\frac{\text { Dominance of woody species }}{\text { Total dominance of all woody species }} * 100 \text {, }
$$

Relative frequency

$$
=\frac{\text { Frequency of woody species }}{\text { Frequency of all woody species }} * 100 \text {. }
$$

2.4. Statistical Analysis. Variation in woody species diversity was tested using one-way ANOVA. Significant differences in mean values for woody species diversity were tested by least significance difference at $P<0.05$. All statistical computations were made using SAS statistical Software version 9.0 [33].

\section{Results}

3.1. Characterizing of the Study Area. The types of traditional agroforestry practices found in the study area included scattered trees, parkland agroforestry, home gardens agroforestry practices, and live fences.

In Chire Kebele, home gardens and parkland agroforestry were more common than in Erba and Burkitu. Live fence types of agroforestry were more common in Erba than the other two Kebeles. In Burkitu Kebele, Mango based home garden and scattered trees types of agroforestry practices were common. In each study site, fruit trees like Mangifera indica are dominantly found.

\subsection{Woody Species Diversity}

3.2.1. Woody Species Richness, Abundance, and Frequency. A total of 55 woody species belonging to 31 families were gathered, identified, and recorded in the traditional agroforestry practices of the study sites (see Appendix). Forty-seven (47) ( $85 \%)$ of these species were indigenous while the remaining 8 species (15\%) were exotic. Anacardiaceae, Bignoniaceae, and Myrtaceae family had the highest number of woody species (7 each), while Apocynaceae, Cupressaceae, Flacourtiaceae, Meliaceae, Papilionoideae, Proteaceae, Rhamnaceae, Santalaceae, and Sapotaceae families had the lowest number of woody species (2 each). Highest numbers of woody species were recorded at Chire while lowest numbers of species were recorded at Erba (Table 1).

The woody species richness for Chire was significantly $(P=0.0202)$ higher than Burkitu and Erba (Table 2).
TABLE 1: Woody species richness in traditional agroforestry practice in Dellomenna District, Southeastern Ethiopia.

\begin{tabular}{lcc}
\hline Kebele & Number of species (richness) & Rank \\
\hline Burkitu & 33 & 2 \\
Chire & 38 & 1 \\
Erba & 28 & 3 \\
\hline
\end{tabular}

TABLE 2: Mean woody species richness and abundance per plot of traditional agroforestry practices in Dellomenna District, Southeastern Ethiopia.

\begin{tabular}{lcc}
\hline Kebeles/site & $\begin{array}{c}\text { Richness } \\
\text { Means }( \pm \text { STD })\end{array}$ & $\begin{array}{c}\text { Abundance } \\
\text { Means }( \pm \text { STD })\end{array}$ \\
\hline Burkitu & $6.13 \pm 1.03^{\mathrm{ab}}$ & $34.13 \pm 4.84^{\mathrm{a}}$ \\
Chire & $8.75 \pm 0.76^{\mathrm{a}}$ & $32.13 \pm 2.79^{\mathrm{a}}$ \\
Erba & $5.94 \pm 0.31^{\mathrm{b}}$ & $30.06 \pm 3.64^{\mathrm{a}}$ \\
\hline Overall mean & $6.94 \pm 1.7$ & $32.1 \pm 3.89$ \\
\hline
\end{tabular}

Note. Different letter(s) ordered vertically on mean values show a significant difference at $P<0.05$ among the three Kebeles.

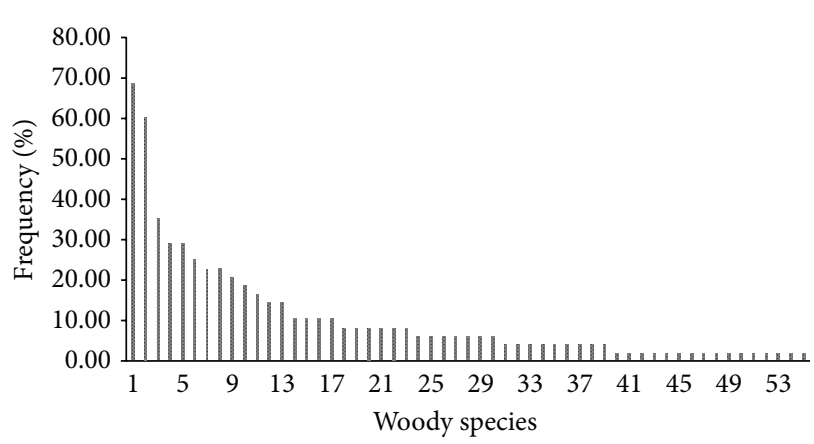

FIGURE 2: Frequency occurrences of woody species across traditional agroforestry practices in Dellomenna District, Southeastern Ethiopia (for more details see Table 10).

However, there was no significant difference in woody species abundance per plot $(P=0.7586)$ among the three Kebeles.

Out of the total 55 woody species found in the area, the dominantly observed species were Croton macrostachyus (68.75\%) followed by Mangifera indica (60.42\%) followed by Persea americana (35.42) while 20 species had the lowest frequency $(2.08 \%)$ (Figure 2).

3.2.2. Diversity Indices. Shannon-Wiener's diversity index indicated that Chire Kebele was more diverse than the other two Kebeles (Table 3). A similar trend was noticed in terms of Simpson's diversity index. Shannon evenness (99\%) indicated that the highest homogeneity of woody species was found in Chire Kebele compared with the other two Kebeles. The lowest Shannon diversity index, Simpson diversity index, and evenness were recorded in Burkitu Kebele. 
TABLE 3: Woody species diversity indices in traditional agroforestry practice in Dellomenna District, Southeastern Ethiopia.

\begin{tabular}{lccc}
\hline \multicolumn{4}{c}{ Diversity indices } \\
Kebele & Shannon & Simpson & Evenness \\
\hline Burkitu & 2.53 & 0.90 & 0.91 \\
Chire & 2.73 & 0.93 & 0.99 \\
Erba & 2.66 & 0.92 & 0.96 \\
\hline
\end{tabular}

TABLE 4: Sorensen's similarity index of woody species in traditional agroforestry practice in Dellomenna District, Southeastern Ethiopia.

\begin{tabular}{|c|c|c|c|}
\hline \multirow{2}{*}{ Kebele } & \multicolumn{3}{|c|}{ Sorensen's similarity index (\%) land use/site name } \\
\hline & Burkitu & Chire & Erba \\
\hline Burkitu & & 50.7 & 55.8 \\
\hline Chire & & & 52.1 \\
\hline Erba & & & \\
\hline
\end{tabular}

TABLE 5: The five woody species with the highest IVIs in traditional agroforestry practices in Dellomenna District, Southeastern Ethiopia.

\begin{tabular}{ccc}
\hline Kebele & Scientific name & Important Value Index (IVI in \%) \\
\hline & Croton macrostachyus & 28.18 \\
& Annona reticulata & 25.11 \\
Burkitu & Calpurnia aurea & 23.1 \\
& Mangifera indica & 22.00 \\
& Casimiroa edulis & 20.01 \\
\hline \multirow{4}{*}{ Chire } & Mangifera indica & 26.38 \\
& Croton macrostachyus & 22.04 \\
& Syzygium guineense & 21.92 \\
& Rhus natalensis & 19.52 \\
Erba & Mangifera indica & 18.69 \\
& Croton macrostachyus & 33.07 \\
& Entada abyssinica & 31.61 \\
& Catha edulis & 30.14 \\
& Rhus natalensis & 24.05 \\
\hline
\end{tabular}

3.2.3. Sorensen's Similarity Index of Woody Species. The similarity of woody species maintained in the three study Kebeles was summarized by Sorensen's similarity index (Table 4). Based on the presence and absence of woody species in the sampled plots, the highest similarity in woody species composition was recorded between Burkitu and Erba while the lowest woody species similarity was recorded between Burkitu and Chire.

The Important Value Index (IVI) of all woody species in the study Kebeles is listed in Appendix. The five woody species with the highest IVIs in each study Kebele are given in descending order in Table 5. The species with the highest IVI were Croton macrostachyus and Annona reticulata in Burkitu,
Mangifera indica and Catha edulis in Chire, and M. indica and C. macrostachyus in Erba.

\section{Discussion}

Woody Species Composition and Diversity. The highest woody species richness in the Chire traditional agroforestry could be due to its relatively well organized irrigation activities compared with the other study Kebeles. The woody species richness of the study area was comparable with another study in Ethiopia ([34]: 64 woody species from Beseku) and lower than a study in Nicaragua ([35]: 83 tree species). In addition, the woody species richness in this study was lower compared with several other studies: for example, 120 trees and shrubs from Sidama in Southern Ethiopia [10], 459 tree and shrub species around Mt. Kenya in central and eastern Kenya [36], 289 woody plants from suburban areas in Sri Lanka [37], and 122 trees and shrubs from Northeast India [38].

The number of woody species per plot recorded in the present study is less when compared with the earlier report of Kindt [39] from Meru, Kenya, in which the average number of species per farm was 54, ranging from 28 to 97 . The total and average number of individual woody species per plot recorded in the present study is also higher than similar studies reported from other locations. For example, Kindt et al. [40] reported 16.6 tree species per farm ranging from 15.7 to 17.5 for western Kenya. The higher woody species abundance per plot in the present study could be because woody species abundance largely depends on the planting pattern of the woody species as reported in home gardens of Sidama [10].

The variation in woody species richness could be due to site characteristics, management strategy, socioeconomic factors [10], and farmers' preferences for tree species and functions in different localities [41]. For example, farmers maintained many tree and shrub species for environmental services like soil and water conservation in the drier regions of the West African Sahel [41]. The frequency of distribution of tree species on farms in the present study was variable. As one would expect, tree species with a greater economic or ecological value or both were found to be frequently distributed across the farms. Mangifera indica was the most frequent species occurring in $97 \%$ of the sampled farms. It is followed by Croton macrostachyus, Entada abyssinica, and Annona reticulate. The low abundance species could indicate that the population size might be too low to sustain these species within the agroecosystem unless their abundance is increased, as reported by O'Neill et al. [42]. Since tree species diversity is required for the long-term survival of species, tree integration on farms could be one of the areas for conservation.

Shannon's diversity index of woody species in this study in traditional agroforestry systems was comparable to the study on Kerala garden in India, ranging from 1.12 to 3 [43], Tolera [44], who recorded Shannon diversity index, Simpson index, and evenness as $2.22,0.83$, and 0.64 , respectively, also comparable to the present study. It is higher than the finding for Sidama home gardens by Abebe [10] and is comparable with the findings in the home gardens of Thailand, which ranges from 1.9 to 2.7 for Shannon index [45]. 
TABLE 6: List of woody species in the overall traditional agroforestry practices in Dellomenna District, Southeastern Ethiopia.

\begin{tabular}{|c|c|c|c|c|}
\hline Number & Local name & Scientific name & Family & Origin $(\mathrm{E} / \mathrm{I})$ \\
\hline 1 & Wanga & Acacia oerfota (A. nubica) & Fabaceae & Indigenous \\
\hline 2 & Karxafa & Acacia senegal & Celastraceae & Indigenous \\
\hline 3 & Karchofe & Albizia gummifera (J.F.Gmel.) C.A. Smith & Mimosaceae & Indigenous \\
\hline 4 & Sarara & Allophylus abyssinicus (Hochst.) Radlk. & Sapindaceae & Indigenous \\
\hline 5 & Gishta & Annona reticulata $\mathrm{L}$. & Annonaceae & Indigenous \\
\hline 6 & Cheekata & Calpurnia aurea (Lam.) Benth. & Fabaceae & Indigenous \\
\hline 7 & Hagamssa & Carissa edulis (Forssk.) Vahl & Apocynaceae & Indigenous \\
\hline 8 & Kasmira & Casimiroa edulis La Llave \& Lex. & Rutaceae & Indigenous \\
\hline 9 & Jimaa & Catha edulis (Vahl) Forssk. ex Endl. & Celastraceae & Indigenous \\
\hline 10 & Meteqamma & Celtis africana & Ulmaceae & Indigenous \\
\hline 11 & Lomii & Citrus aurantifolia (Christm.) Swingle & Rutaceae & Indigenous \\
\hline 12 & Burtukana & Citrus sinensis (L.) Osbeck & Rutaceae & Indigenous \\
\hline 13 & Dhandhaasa & Combretum ghasalense Engl. \& Diels & Combretaceae & Indigenous \\
\hline 14 & Waddessa & Cordia africana Lam. & Boraginaceae & Indigenous \\
\hline 15 & Bakanisa & Croton macrostachyus Hochst. ex Del. & Euphorbiaceae & Indigenous \\
\hline 16 & Lookoo & Diospyros abyssinica (Hiern) White & Ebenaceae & Indigenous \\
\hline 17 & Kolati & Diospyros mespiliformis Hochst. ex A. & Ebenaceae & Indigenous \\
\hline 18 & Ruukeessa & Dracaena afromontana Mildbr. & Agavaceae & Indigenous \\
\hline 19 & Waleensu & Erythrina brucei Schweinf. & Papilionoideae & Indigenous \\
\hline 20 & Ulaagaa & Ehretia cymosa Thonn. & Boraginaceae & Indigenous \\
\hline 21 & Kontir & Entada abyssinica Steudel ex A. Rich. & Mimosoideae & Indigenous \\
\hline 22 & Nech bahirzaf & Eucalyptus globulus Labill. & Myrtaceae & Exotic \\
\hline 23 & Miheesa & Euclea schimperi & Ebenaceae & Indigenous \\
\hline 24 & Qiltu & Ficus vasta Forssk. & Moraceae & Indigenous \\
\hline 25 & Muluqaa & Filicium decipiens & Sapindaceae & Indigenous \\
\hline 26 & Akukkuu & Flacourtia indica (Eleusinej) & Flacourtiaceae & Indigenous \\
\hline 27 & Grevillea & Grevillea robusta & Proteaceae & Exotic \\
\hline 28 & Honcho & Juniperus procera (Hochst. ex. Endl.) & Cupressaceae & Indigenous \\
\hline 29 & Andarku & Lannea schimperi & Anacardiaceae & Indigenous \\
\hline 30 & Lucinaa & Leucaena leucocephala (Lam.) de Wit & Mimosoideae & Exotic \\
\hline 31 & Mango & Mangifera indica L. & Anacardiaceae & Exotic \\
\hline 32 & Kombolcha & Maytenus arbutifolia & Celastraceae & Indigenous \\
\hline 33 & Kinin zaf & Melia azedarach L. & Meliaceae & Exotic \\
\hline 34 & Qolati & Mimusops kummel & Sapotaceae & Indigenous \\
\hline 35 & Onomaa & Olea capensis & Oleaceae & Indigenous \\
\hline 36 & Gagama & Olea capensis subsp. macrocarpa & Oleaceae & Indigenous \\
\hline 37 & Ejerssaa & Olea europaea subsp. cuspidata & Oleaceae & Indigenous \\
\hline 38 & Waatoo & Osyris compressa Decn & Santalaceae & Indigenous \\
\hline 39 & Avocado & Persea americana Mill. & Lauraceae & Exotic \\
\hline 40 & Lilluu & Piliostigma thonningii (Schum.) & Caesalpiniaceae & Indigenous \\
\hline 41 & Birbirsa & Podocarpus falcatus (Thunb.) & Podocarpaceae & Indigenous \\
\hline 42 & Zeytuna & Psidium guajava L. & Myrtaceae & Exotic \\
\hline 43 & Dabaqaa & Rhus natalensis & Anacardiaceae & Indigenous \\
\hline 44 & Koboo & Ricinus communis $\mathrm{L}$. & Euphorbiaceae & Indigenous \\
\hline 45 & Qondabarbere & Schinus molle L. & Anacardiaceae & Exotic \\
\hline 46 & Horoqa & Spathodea campanulata (S.nilotica) & Bignoniaceae & Indigenous \\
\hline 47 & Badeesa & Syzygium guineense (Willd.) DC & Myrtaceae & Indigenous \\
\hline 48 & Hadheessa & Teclea nobilis Del. & Rutaceae & Indigenous \\
\hline 49 & Tala’aa & Trema orientalis (L.) Blume & Ulmaceae & Indigenous \\
\hline 50 & Gurbii & Triumfetta pentandra A. Rich & Tiliaceae & Indigenous \\
\hline
\end{tabular}


TABle 6: Continued.

\begin{tabular}{lcccc}
\hline Number & Local name & Scientific name & Family & Origin (E/I) \\
\hline 51 & Ebicha & Vernonia amygdalina Del. & Asteraceae & Indigenous \\
52 & Rejii & Vernonia auriulifera Hiern & Asteraceae & Indigenous \\
53 & Arabee & Verprise dainelli & Rutaceae & Indigenous \\
54 & Bifti/kanafa & Warburgia ugandensis & Canellaceae & Indigenous \\
55 & Kankura & Ziziphus spp. & Rhamnaceae & Indigenous \\
\hline
\end{tabular}

E: exotic; I: indigenous.

TABLE 7: List of woody species and their Important Value Index in traditional agroforestry of Burkitu Kebele in Dellomenna District, Southeastern Ethiopia.

\begin{tabular}{|c|c|c|c|c|c|c|c|c|c|}
\hline Number & Scientific name & Family & Fre & RF\% & $\mathrm{AB}$ & $\mathrm{RAB} \%$ & $\mathrm{DBH}(\mathrm{cm})$ & $\mathrm{RD}(\%)$ & IVI\% \\
\hline 1 & Annona reticulata $\mathrm{L}$. & Annonaceae & 9 & 10.23 & 66 & 14.44 & 15.70 & 0.44 & 25.11 \\
\hline 2 & Calpurnia aurea (Lam.) & Fabaceae & 3 & 3.41 & 90 & 19.69 & 0.00 & 0.00 & 23.10 \\
\hline 3 & Casimiroa edulis La Llave \& Lex. & Rutaceae & 4 & 4.55 & 61 & 13.35 & 34.57 & 2.11 & 20.01 \\
\hline 4 & Combretum ghasalense Engl. & Combretaceae & 6 & 6.82 & 47 & 10.28 & 14.50 & 0.37 & 17.47 \\
\hline 5 & Croton macrostachyus Hochst. & Euphorbiaceae & 21 & 23.86 & 7 & 1.53 & 39.65 & 2.78 & 28.18 \\
\hline 6 & Diospyros abyssinica (Hiern.) & Ebenaceae & 1 & 1.14 & 3 & 0.66 & 90.13 & 14.37 & 16.17 \\
\hline 7 & Diospyros mespiliformis Hochst. & Ebenaceae & 3 & 3.41 & 10 & 2.19 & 0.00 & 0.00 & 5.60 \\
\hline 8 & Dracaena afromontana Mildbr. & Agavaceae & 3 & 3.41 & 19 & 4.16 & 68.80 & 8.38 & 15.94 \\
\hline 9 & Entada abyssinica & Mimosoideae & 3 & 3.41 & 23 & 5.03 & 58.39 & 6.03 & 14.47 \\
\hline 10 & Ficus vasta Forssk. & Moraceae & 1 & 1.14 & 1 & 0.22 & 73.25 & 9.49 & 10.85 \\
\hline 11 & Filicium decipiens & Sapindaceae & 1 & 1.14 & 3 & 0.66 & 65.81 & 7.66 & 9.46 \\
\hline 12 & Flacourtia indica (Eleusinej) & Flacourtiaceae & 2 & 2.27 & 2 & 0.44 & 60.51 & 6.48 & 9.19 \\
\hline 13 & Lannea schimperi & Anacardiaceae & 3 & 3.41 & 15 & 3.28 & 0.00 & 0.00 & 6.69 \\
\hline 14 & Mangifera indica $\mathrm{L}$. & Anacardiaceae & 10 & 11.36 & 40 & 8.75 & 32.66 & 1.89 & 22.00 \\
\hline 15 & Maytenus arbutifolia & Celastraceae & 1 & 1.14 & 1 & 0.22 & 50.00 & 4.42 & 5.78 \\
\hline 16 & Olea capensis & Oleaceae & 2 & 2.27 & 15 & 3.28 & 0.00 & 0.00 & 5.56 \\
\hline 17 & Olea capensis subsp. macrocarpa & Oleaceae & 2 & 2.27 & 3 & 0.66 & 36.05 & 2.30 & 5.23 \\
\hline 18 & Olea europaea subsp. cuspidata & Oleaceae & 1 & 1.14 & 1 & 0.22 & 45.00 & 3.58 & 4.94 \\
\hline 19 & Persea americana Mill. & Lauraceae & 2 & 2.27 & 2 & 0.44 & 33.95 & 2.04 & 4.75 \\
\hline 20 & Piliostigma thonningii (Schum.) & Caesalpiniaceae & 3 & 3.41 & 3 & 0.66 & 8.27 & 0.12 & 4.19 \\
\hline 21 & Podocarpus falcatus (Thunb.) & Podocarpaceae & 1 & 1.14 & 1 & 0.22 & 40.00 & 2.83 & 4.19 \\
\hline 22 & Psidium guajava L. & Myrtaceae & 1 & 1.14 & 1 & 0.22 & 38.22 & 2.58 & 3.94 \\
\hline 23 & Rhus natalensis & Anacardiaceae & 2 & 2.27 & 2 & 0.44 & 18.00 & 0.57 & 3.28 \\
\hline 24 & Rhus natalensis Benth. & Anacardiaceae & 1 & 1.14 & 12 & 2.63 & 0.00 & 0.00 & 3.76 \\
\hline 25 & Ricinus communis $\mathrm{L}$. & Euphorbiaceae & 2 & 2.27 & 5 & 1.09 & 0.00 & 0.00 & 3.37 \\
\hline 26 & Syzygium guineense (Willd.) & Myrtaceae & 1 & 1.14 & 4 & 0.88 & 0.00 & 0.00 & 2.01 \\
\hline 27 & Trema orientalis & Ulmaceae & 1 & 1.14 & 2 & 0.44 & 10.80 & 0.21 & 1.78 \\
\hline 28 & Triumfetta pentandra A. Rich & Tiliaceae & 1 & 1.14 & 1 & 0.22 & 6.00 & 0.06 & 1.42 \\
\hline 29 & Vernonia amygdalina Del. & Asteraceae & 1 & 1.14 & 1 & 0.22 & 0.00 & 0.00 & 1.36 \\
\hline 30 & Vernonia auriulifera Hiern & Asteraceae & 1 & 1.14 & 1 & 0.22 & 0.00 & 0.00 & 1.36 \\
\hline 31 & Verprise dainelli & Rutaceae & 1 & 1.14 & 1 & 0.22 & 0.00 & 0.00 & 1.36 \\
\hline 32 & Warburgia ugandensis & Canellaceae & 1 & 1.14 & 1 & 0.22 & 0.00 & 0.00 & 1.36 \\
\hline 33 & Ziziphus spp. & Rhamnaceae & 1 & 1.14 & 1 & 0.22 & 0.00 & 0.00 & 1.36 \\
\hline
\end{tabular}

Fre: frequency; RF: relative frequency; $\mathrm{AB}$ : abundance; RAB: relative abundance; RD: relative dominance. 
TABLE 8: List of woody species and their Important Value Index in traditional agroforestry practices in Chire Kebele in Dellomenna District, Southeastern Ethiopia.

\begin{tabular}{|c|c|c|c|c|c|c|c|c|c|}
\hline Number & Scientific name & Family & Fre & $\mathrm{RF} \%$ & $\mathrm{DBH}(\mathrm{cm})$ & $\mathrm{RD} \%$ & $\mathrm{AB}$ & $\mathrm{RAB} \%$ & IVI\% \\
\hline 1 & Acacia senegal & Celastraceae & 2 & 1.527 & 0.0 & 0 & 2 & 0.40 & 1.93 \\
\hline 2 & Albizia gummifera (J.F.Gmel.) & Mimosaceae & 1 & 0.763 & 21.0 & 2.69 & 6 & 1.21 & 4.66 \\
\hline 3 & Allophylus abyssinicus (Hochst.) & Sapindaceae & 1 & 0.763 & 0.0 & 0 & 1 & 0.20 & 0.96 \\
\hline 4 & Annona reticulata $\mathrm{L}$. & Annonaceae & 1 & 0.763 & 12.5 & 0.95 & 2 & 0.40 & 2.12 \\
\hline 5 & Calpurnia aurea (Lam.)Benth. & Fabaceae & 5 & 3.817 & 0.0 & 0 & 13 & 2.62 & 6.43 \\
\hline 6 & Carissa edulis (Forssk.)Vahl & Apocynaceae & 1 & 0.763 & 0.0 & 0 & 2 & 0.40 & 1.17 \\
\hline 7 & Catha edulis (Vahl)Forssk. ex Endl. & Celastraceae & 7 & 5.344 & 0.0 & 0 & 83 & 16.70 & 22.04 \\
\hline 8 & Combretum ghasalense Engl. \& Diels & Combretaceae & 5 & 3.817 & 7.0 & 0.3 & 42 & 8.45 & 12.57 \\
\hline 9 & Cordia africana Lam. & Boraginaceae & 3 & 2.290 & 29.0 & 5.14 & 4 & 0.80 & 8.23 \\
\hline 10 & Croton macrostachyus Hochst. ex Del. & Euphorbiaceae & 12 & 9.160 & 24.0 & 3.5 & 46 & 9.26 & 21.92 \\
\hline 11 & Dracaena afromontana Mildbr. & Agavaceae & 4 & 3.053 & 15.1 & 1.4 & 17 & 3.42 & 7.87 \\
\hline 12 & Erythrina brucei Schweinf. & Papilionoideae & 1 & 0.763 & 38.0 & 8.82 & 1 & 0.20 & 9.79 \\
\hline 13 & Ehretia cymosa Thonn. & Boraginaceae & 1 & 0.763 & 7.0 & 0.3 & 1 & 0.20 & 1.26 \\
\hline 14 & Entada abyssinica (Steudel) & Mimosoideae & 10 & 7.634 & 0.0 & 0 & 50 & 10.06 & 17.69 \\
\hline 15 & Euclea schimperi & Ebenaceae & 3 & 2.290 & 10.0 & 0.61 & 7 & 1.41 & 4.31 \\
\hline 16 & Ficus vasta Forssk. & Moraceae & 1 & 0.763 & 38.0 & 8.82 & 1 & 0.20 & 9.79 \\
\hline 17 & Ficus vasta Forssk. & Moraceae & 1 & 0.763 & 0.0 & 0 & 2 & 0.40 & 1.17 \\
\hline 18 & Grevillea robusta & Proteaceae & 1 & 0.763 & 0.0 & 0 & 4 & 0.80 & 1.57 \\
\hline 19 & Juniperus procera (Hochst. ex Endl.) & Cupressaceae & 1 & 0.763 & 0.0 & 0 & 1 & 0.20 & 0.96 \\
\hline 20 & Mangifera indica L. & Anacardiaceae & 14 & 10.687 & 15.2 & 1.4 & 71 & 14.29 & 26.38 \\
\hline 21 & Maytenus gracilipes & Celastraceae & 1 & 0.763 & 0.0 & 0 & 8 & 1.61 & 2.37 \\
\hline 22 & Mimusops kummel & Sapotaceae & 1 & 0.763 & & 0 & 1 & 0.20 & 0.96 \\
\hline 23 & Olea capensis subsp. macrocarpa & Oleaceae & 1 & 0.763 & 9.0 & 0.49 & 1 & 0.20 & 1.46 \\
\hline 24 & Olea capensis subsp. macrocarpa (O. hochstetteri) & Oleaceae & 1 & 0.763 & 0.0 & 0 & 1 & 0.20 & 0.96 \\
\hline 25 & Olea europaea subsp. cuspidata & Oleaceae & 1 & 0.763 & 51.0 & 15.9 & 8 & 1.61 & 18.23 \\
\hline 26 & Osyris compressa Decn & Santalaceae & 1 & 0.763 & 0.0 & 0 & 2 & 0.40 & 1.17 \\
\hline 27 & Persea americana Mill. & Lauraceae & 6 & 4.580 & 25.8 & 4.07 & 12 & 2.41 & 11.07 \\
\hline 28 & Piliostigma thonningii (Schum.) & Caesalpiniaceae & 2 & 1.527 & 19.6 & 2.35 & 2 & 0.40 & 4.28 \\
\hline 29 & Podocarpus falcatus (Thunb.) & Podocarpaceae & 1 & 0.763 & 8.0 & 0.39 & 1 & 0.20 & 1.36 \\
\hline 30 & Psidium guajava $\mathrm{L}$. & Myrtaceae & 3 & 2.290 & 13.4 & 1.1 & 3 & 0.60 & 4.00 \\
\hline 31 & Ricinus communis $\mathrm{L}$. & Euphorbiaceae & 2 & 1.527 & 9.3 & 0.53 & 3 & 0.60 & 2.66 \\
\hline 32 & Spathodea campanulata & Bignoniaceae & 2 & 1.527 & 11.8 & 0.85 & 11 & 2.21 & 4.59 \\
\hline 33 & Rhus natalensis & Anacardiaceae & 8 & 6.107 & 37.0 & 8.36 & 21 & 4.23 & 18.70 \\
\hline 34 & Syzygium guineense (Willd.) & Myrtaceae & 11 & 8.397 & 25.9 & 4.09 & 35 & 7.04 & 19.52 \\
\hline 35 & Teclea nobilis Del. & Rutaceae & 1 & 0.763 & 0.0 & 0 & 2 & 0.40 & 1.17 \\
\hline 36 & Vernonia amygdalina Del. & Asteraceae & 1 & 0.763 & 0.0 & 0 & 5 & 1.01 & 1.77 \\
\hline 37 & Vernonia auriulifera Hiern & Asteraceae & 7 & 5.344 & 24.0 & 3.52 & 13 & 2.62 & 11.48 \\
\hline 38 & Warburgia ugandensis & Canellaceae & 1 & 0.763 & 3.0 & 0.05 & 2 & 0.40 & 1.22 \\
\hline
\end{tabular}

Fre: frequency; RF: relative frequency; RD: relative dominancy; $\mathrm{AB}$ : abundance; RA: relative abundance.

The IVI is an aggregate index that summarizes the density, abundance, and distribution of a species. It measures the overall importance of a species and gives an indication of the ecological success of a species in a particular area. The tree species with the highest IVI recorded in traditional agroforestry were $M$. indica, Entada abyssinica, and $C$. macrostachyus. The IVI values can also be used to prioritize species for conservation, and species with high IVI value need less conservation efforts, whereas those having low IVI value need high conservation effort. 
TABLE 9: List of woody species and their Important Value Index in traditional agroforestry practices in Erba Kebele in Dellomenna District, Southeastern Ethiopia.

\begin{tabular}{|c|c|c|c|c|c|c|c|c|c|}
\hline \multirow{2}{*}{ Number } & \multirow{2}{*}{ Scientific name } & \multirow{2}{*}{ Family } & \multirow{2}{*}{ Fre } & \multirow{2}{*}{$\mathrm{RF} \%$} & \multicolumn{5}{|c|}{$\mathrm{RE}$} \\
\hline & & & & & $\mathrm{DBH}(\mathrm{cm})$ & $\mathrm{RD} \%$ & $\mathrm{AB}$ & $\mathrm{AB} \%$ & IVI\% \\
\hline 1 & Acacia oerfota (A. nubica) & Fabaceae & 1 & 1.10 & 0 & 0 & 1 & 0.25 & 1.35 \\
\hline 2 & Annona reticulata $\mathrm{L}$. & Annonaceae & 8 & 8.79 & 10.7 & 0.58 & 13 & 3.23 & 12.60 \\
\hline 3 & Calpurnia aurea (Lam.) & Fabaceae & 1 & 1.10 & 0.0 & 0 & 9 & 2.24 & 3.34 \\
\hline 4 & Catha edulis (Vahl) & Celastraceae & 4 & 4.40 & 0.0 & 0 & 79 & 19.65 & 24.05 \\
\hline 5 & Celtis africana & Ulmaceae & 1 & 1.10 & 5.2 & 0.14 & 1 & 0.25 & 1.49 \\
\hline 6 & Citrus aurantifolia (Christm.) & Rutaceae & 3 & 3.30 & 9.0 & 0.41 & 13 & 3.23 & 6.94 \\
\hline 7 & Citrus sinensis (L.) & Rutaceae & 1 & 1.10 & 12.0 & 0.73 & 1 & 0.25 & 2.08 \\
\hline 8 & Combretum ghasalense Engl. & Combretaceae & 1 & 1.10 & 0.0 & 0 & 1 & 0.25 & 1.35 \\
\hline 9 & Cordia Africana & Boraginaceae & 1 & 1.10 & 13.0 & 0.86 & 1 & 0.25 & 2.21 \\
\hline 10 & Croton macrostachyus Hochst. & Euphorbiaceae & 10 & 10.99 & 37.5 & 7.19 & 54 & 13.43 & 31.61 \\
\hline 11 & Entada abyssinica & Mimosoideae & 10 & 10.99 & 0.0 & 0 & 77 & 19.15 & 30.14 \\
\hline 12 & Eucalyptus globulus Labill. & Myrtaceae & 1 & 1.10 & 23.5 & 2.82 & 2 & 0.50 & 4.41 \\
\hline 13 & Leucaena leucocephala (Lam.) & Mimosoideae & 1 & 1.10 & 5.5 & 0.15 & 1 & 0.25 & 1.50 \\
\hline 14 & Mangifera indica L. & Anacardiaceae & 14 & 15.38 & 15.8 & 1.27 & 66 & 16.42 & 33.07 \\
\hline 15 & Melia azedarach L. & Meliaceae & 3 & 3.30 & 15.4 & 1.20 & 5 & 1.24 & 5.74 \\
\hline 16 & Olea europaea (Mill.) & Oleaceae & 1 & 1.10 & 24.8 & 3.14 & 1 & 0.25 & 4.49 \\
\hline 17 & Persea americana Mill. & Lauraceae & 5 & 5.49 & 18.2 & 1.70 & 12 & 2.99 & 10.18 \\
\hline 18 & Piliostigma thonningii (Schum.) & Caesalpiniaceae & 2 & 2.20 & 12.6 & 0.80 & 2 & 0.50 & 3.50 \\
\hline 19 & Psidium guajava L. & Myrtaceae & 4 & 4.40 & 12.7 & 0.83 & 15 & 3.73 & 8.96 \\
\hline 20 & Rhus natalensis & Anacardiaceae & 3 & 3.30 & 55.5 & 15.73 & 5 & 1.24 & 20.27 \\
\hline 21 & Ricinus communis $\mathrm{L}$. & Euphorbiaceae & 1 & 1.10 & 13.6 & 0.94 & 1 & 0.25 & 2.28 \\
\hline 22 & Schinus molle L. & Anacardiaceae & 1 & 1.10 & 29.0 & 4.29 & 1 & 0.25 & 5.64 \\
\hline 23 & Spathodea campanulata & Bignoniaceae & 1 & 1.10 & 38.0 & 7.37 & 1 & 0.25 & 8.72 \\
\hline 24 & Syzygium guineense (Willd.) & Myrtaceae & 2 & 2.20 & 35.4 & 6.39 & 5 & 1.24 & 9.84 \\
\hline 25 & Trema orientalis (L.) Blume & Ulmaceae & 1 & 1.10 & 32.0 & 5.22 & 1 & 0.25 & 6.57 \\
\hline 26 & Triumfetta pentandra A. Rich & Tiliaceae & 2 & 2.20 & 0.0 & 0 & 5 & 1.24 & 3.44 \\
\hline 27 & Vernonia amygdalina Del. & Asteraceae & 1 & 1.10 & 21.3 & 2.31 & 2 & 0.50 & 3.91 \\
\hline 28 & Vernonia auriulifera Hiern & Asteraceae & 1 & 1.10 & 0 & 0 & 5 & 1.24 & 2.34 \\
\hline
\end{tabular}

Fre: frequency; RF: relative frequency; RD: relative dominancy; $\mathrm{AB}$ : abundance; RA: relative abundance.

\section{Conclusion and Recommendations}

The results of the present study confirm that traditional agroforestry practices play a major role in the conservation of native woody species like Syzygium guineense and Juniperus procera which are endemic to Ethiopia and the critically endangered species like Cordia africana and $C$. macrostachyus. Based on the results obtained from the study, the following recommendations are offered: This study focused mainly on the assessment of the woody species diversity in traditional agroforestry practices; hence, in-depth assessment of all natural habitats is important to quantify the status of native woody species in the area. Creating awareness at the grass roots level about wise utilization of the woody species in the area is crucial in order to prevent the loss of valuable tree species. The governmental and nongovernmental organizations should promote different agroforestry practices to conserve indigenous woody species through circa situm conservation.

\section{Appendix}

See Tables 6, 7, 8, and 9.

\section{Conflict of Interests}

The authors declare that there is no conflict of interests regarding the publication of this paper. 
TABLE 10: Legend of Figure 2.

\begin{tabular}{|c|c|}
\hline Number & Scientific name \\
\hline 1 & Croton macrostachyus \\
\hline 2 & Mangifera indica \\
\hline 3 & Persea americana \\
\hline 4 & Entada abyssinica \\
\hline 5 & Syzygium guineense \\
\hline 6 & Rhus natalensis \\
\hline 7 & Annona reticulata \\
\hline 8 & Catha edulis \\
\hline 9 & Vernonia auriulifera \\
\hline 10 & Flacourtia indica \\
\hline 11 & Psidium guajava \\
\hline 12 & Calpurnia aurea \\
\hline 13 & Combretum ghasalense \\
\hline 14 & Dracaena afromontana \\
\hline 15 & Olea europaea \\
\hline 16 & Piliostigma thonningii \\
\hline 17 & Triumfetta pentandra \\
\hline 18 & Cordia africana \\
\hline 19 & Podocarpus falcatus \\
\hline 20 & Ricinus communis \\
\hline 21 & Vernonia amygdalina \\
\hline 22 & Verprise dainelli \\
\hline 23 & Dracaena afromontana \\
\hline 24 & Citrus aurantifolia \\
\hline 25 & Euclea schimperi \\
\hline 26 & Ficus vasta Forssk. \\
\hline 27 & Filicium decipiens \\
\hline 28 & Lannea schimperi \\
\hline 29 & Maytenus arbutifolia \\
\hline 30 & Melia azedarach \\
\hline 31 & Acacia senegal \\
\hline 32 & Casimiroa edulis \\
\hline 33 & Mimusops kummel \\
\hline 34 & Olea capensis \\
\hline 35 & Olea capensis subsp. macrocarpa \\
\hline 36 & Spathodea campanulata (S.nilotica) \\
\hline 37 & Trema orientalis \\
\hline 38 & Warburgia ugandensis \\
\hline 39 & Ziziphus spp. \\
\hline 40 & Acacia oerfota \\
\hline 41 & Albizia gummifera \\
\hline 42 & Allophylus abyssinicus \\
\hline 43 & Carissa edulis \\
\hline 44 & Celtis africana \\
\hline 45 & Citrus sinensis \\
\hline 46 & Diospyros abyssinica \\
\hline 47 & Erythrina brucei \\
\hline 48 & Ehretia cymosa \\
\hline 49 & Eucalyptus globulus \\
\hline 50 & Grevillea robusta \\
\hline 51 & Juniperus procera \\
\hline
\end{tabular}

TABLE 10: Continued.

\begin{tabular}{lc}
\hline Number & Scientific name \\
\hline 52 & Leucaena leucocephala \\
53 & Osyris compressa \\
54 & Schinus molle \\
55 & Teclea nobilis \\
\hline
\end{tabular}

\section{Acknowledgments}

The authors are grateful to Madda Walabu University for financial support for the research work. The authors also thank Dellomenna District Pastoral Development Office for their cooperation during the field work. They also acknowledge the development agents of the three Kebeles for their cooperation and farmers who opened the gates of their farm land as well as those people who provided their supports directly or indirectly for the successful accomplishment of this research.

\section{References}

[1] Ministry of Mines and Energy (MoME), Geological Survey of Ethiopia: Industrial Minerals and Rocks Resource Potentials of Ethiopia, Ministry of Mines and Energy (MoME), Addis Ababa, Ethiopia, 2003.

[2] E. Feoli, L. G. Vuerich, and Z. Woldu, "Processes of environmental degradation and opportunities for rehabilitation in Adwa, Northern Ethiopia," Landscape Ecology, vol. 17, no. 4, pp. 315-325, 2002.

[3] B. Bishaw and Z. Asfaw, Water Resources Management in Ethiopia: Implications for the Nile Basin, Hydrological and Related Aspects of Deforestation and Degradation of Woody Vegetation, Cambria Press, Amherst, NY, USA, 2010.

[4] ICRAF, "Agroforestry potentials for the Ethiopian highlands," Working Paper, International Centre for research in Agroforestry (ICRAF), Nairobi, Kenya, 1997.

[5] P. K. Shukla, "Nutrient dynamics of tea plantations and their impact on soil productivity-a case study from India," in Proceedings of the 8th World Forestry Congress, pp. 1-11, Buenos Aires, Argentina, October 2009.

[6] B. Manjur, T. Abebe, and A. Abdulkadir, "Effects of scattered F. albida (Del) and C. macrostachyus (Lam) tree species on key soil physicochemical properties and grain yield of Maize (Zea Mays): a case study at umbulo Wacho watershed, southern Ethiopia," Wudpecker Journal of Agricultural Research, vol. 3, no. 3, pp. 63-73, 2014.

[7] G. Kewessa, L. Tiki, and A. Molla, "Effects of Hypericum revolutum (Vahl) tree on major soil nutrients and on selected soil physico-chemical properties in Goba District, Oromia, Ethiopia," Wudpecker Journal of Agricultural Research, vol. 4, no. 1, pp. 6-13, 2015.

[8] G. D. Schroth, G. A. B. Fonseca, C. A. Harvey, C. Gascon, and H. A. N. Vasconcelos, Agroforestry and Biodiversity Conservation in Tropical Landscapes, Island Press, Washington, DC, USA, 2004.

[9] Z. Asfaw, Tree species diversity, top soil conditions and arbuscular mycorrhizal association in the Sidama traditional agroforestry land-use, Southern Ethiopia [Ph.D. dissertation], Swedish University of Agriculture, Uppsala, Sweden, 2003. 
[10] T. Abebe, Diversity in homegarden agroforestry systems in Southern Ethiopia [Ph.D. thesis], Wageningen University, Wageningen, The Netherlands, 2005.

[11] C. A. Harvey and W. A. Haber, "Remnant trees and the conservation of biodiversity in Costa Rican pastures," Agroforestry Systems, vol. 44, no. 1, pp. 37-68, 1998.

[12] I. K. Dawson, A. Lengkeek, J. C. Weber, and R. Jamnadass, "Managing genetic variation in tropical trees: linking knowledge with action in agroforestry ecosystems for improved conservation and enhanced livelihoods," Biodiversity and Conservation, vol. 18, no. 4, pp. 969-986, 2009.

[13] I. K. Dawson, M. R. Guariguata, J. Loo et al., "What is the relevance of smallholders' agroforestry systems for conserving tropical tree species and genetic diversity in circa situm, in situ and ex situ settings? A review," Biodiversity and Conservation, vol. 22, no. 2, pp. 301-324, 2013.

[14] J. A. McNeely, "Nature vs. nurture: managing relationships between forests, agroforestry and wild biodiversity," Agroforestry Systems, vol. 61, pp. 155-165, 2004.

[15] C. A. Harvey, J. Gonzalez, and E. Somarriba, "Dung beetle and terrestrial mammal diversity in forests, indigenous agroforestry systems and plantain monocultures in Talamanca, Costa Rica," Biodiversity and Conservation, vol. 15, no. 2, pp. 555-585, 2006.

[16] V. S. Singh and D. N. Pandey, "Multifunctional agroforestry systems in India: science-based policy options," RSPCB Occasional Paper 4/2011, 2011.

[17] S. Feyera, Biodiversity and Ecology of Afromontane Rainforest with Wild Coffee Arabica L. Populations in Ethiopia, Ecology and Development Series no. 38, Cuvillier, Göttingen, Germany, 2006.

[18] W. Tadesse and S. Feyera, Sustainable Management and Promotion of Forest Coffee in Bale, Ethiopia, Bale Eco-Region Sustainable Management Program, SOS Sahel/FARM-Africa, Addis Ababa, Ethiopia, 2008.

[19] A. Worku, Status of traditional agroforestry and its future potential development as buffer zone agroforestry for the natural forest conservation in burkitu peasant association, Oromia, Ethiopia [M.S. thesis], Hawassa University Wondo Genet Colleg of Forestry and Natural Resources, Sheshamane, Ethiopia, 2009.

[20] A. S. Salim, A. J. Simons, C. Orwa, J. Chege, B. Owuor, and A. Mutua, Agroforestry Database. A Tree Species Reference and Selection Guide, Version 2.0, World Agroforestry Centre, Nairobi, Kenya, 2002.

[21] A. Bekele, Useful Trees and Shrubs for Ethiopia, RSCU, Nairobi, Kenya, 1993.

[22] A. Bekele, Useful Trees of Ethiopia: Identification, Propagation and Management in 17 Agro-Ecological Zones, RELMA in ICRAF Project, Nairobi, Kenya, 2007.

[23] S. Edwards, T. Mesfin, and Hedberg, Flora of Ethiopia and Eritrea, Vol. 2, Part 2. The National Herbarium, Addis Ababa University, Addis Ababa, Ethiopia; Department of Systematic Botany, Uppsala University, Uppsala, Sweden, 1995.

[24] I. Hedberg, B. Friis, and S. Edwards, Flora of Ethiopia and Eritrea, Vol. 5, Part 2. Asteraceae (Compositae), The National Herbarium, Addis Ababa University, Addis Ababa, Ethiopia; Department of Systematic Botany, Uppsala University, Uppsala, Sweden, 2004.

[25] I. Hedberg, E. Kelbessa, S. Edwards, S. Demissiew, and E. Persson, Flora of Ethiopia and Eritrea, vol. 7 of Gentianaceae to Cyclocheilaceae, The National Herbarium, Addis Ababa University, Addis Ababa, Ethiopia; Department of Systematic Botany, Uppsala University, Uppsala, Sweden, 2006.
[26] K. G. Mac Diken, A Guide to Monitoring Carbon Storage in Forestry and Agroforestry Prooects, Winrock International, Arlington, Va, USA, 1997.

[27] M. Segura, M. Kanninen, and D. Suárez, "Allometric models for estimating aboveground biomass of shade trees and coffee bushes grown together," Agroforestry Systems, vol. 68, no. 2, pp. 143-150, 2006.

[28] R. P. Hernandez, P. Koohafkan, and J. Antoine, Assessing Carbon Stocks and Modeling Win-Win Scenarios of Carbon Sequestration through Land-Use Changes, Food and Agriculture Organization of the United Nations, Rome, Italy, 2004.

[29] C. J. Krebs, Ecological Methodology, vol. 2nd, Addison Wesley Longman, Menlo Park, Calif, USA, 1999.

[30] C. J. Krebs, The Experimental Analysis of Distribution and Abundance, Harper \& Row Publishers, New York, NY, USA, 1985.

[31] M. Kent and P. Coker, Vegetation Description and Analysis: A Practical Approach, Belhaven Press, London, UK, 1992.

[32] A. E. Magurran, Ecological Diversity and Its Measurement, Croom Helm, London, UK, 1988.

[33] SAS (Statistical Analysis Software), SAS, User's Guide, Version 16.0, GLM-VARCOMP, SAS Institute Incorporation, Gary, North Carolina, 4th edition, 2004.

[34] M. Tolera, Z. Asfaw, M. Lemenih, and E. Karltun, "Woody species diversity in a changing landscape in the south-central highlands of Ethiopia," Agriculture, Ecosystems and Environment, vol. 128, no. 1-2, pp. 52-58, 2008.

[35] V. E. Méndez, R. Lok, and E. Somarriba, "Interdisciplinary analysis of homegardens in Nicaragua: micro-zonation, plant use and socioeconomic importance," Agroforestry Systems, vol. 51, no. 2, pp. 85-96, 2001.

[36] Z. Oginosako, P. Simitu, C. Orwa, and S. Mathenge, "Are they competing or compensating on farm? Status of indigenous and exotic tree species in a wide range of agro-ecological zones of Eastern and Central Kenya, surrounding Mt. Kenya," ICRAF Working Paper 16, World Agroforestry Centre, Nairobi, Kenya, 2006.

[37] M. A. Sandya Kumari, Plant diversity in home gardens and its contribution to household economy in Suburban areas in Sri Lanka [M.S. thesis], Mahidol University, Salaya, Thailand, 2009.

[38] T. Das and A. K. Das, "Inventorying plant biodiversity in homegardens: a case study in Barak Valley, Assam, North East India," Current Science, vol. 89, no. 1, pp. 155-163, 2005.

[39] R. Kindt, Methodology for tree species diversification planning for African agroecosystems [Ph.D. thesis], Faculty of Agricultural and Applied Biological Sciences, Ghent, Belgium, 2002.

[40] R. Kindt, A. J. Simons, and P. V. Damme, "Do farm characteristics explain differences in tree species diversity among western Kenyan farms?" Agroforestry Systems, vol. 63, no. 1, pp. 63-74, 2005.

[41] M. D. Faye, J. C. Weber, T. A. Abasse et al., "Farmers' preferences for tree functions and species in the West African Sahel," Forests Trees and Livelihoods, vol. 20, no. 2-3, pp. 113-136, 2011.

[42] G. A. O'Neill, I. K. Dawson, C. Sotelo-Montes et al., "Strategies for genetic conservation of trees in the Peruvian Amazon basin," Biodiversity and Conservation, vol. 10, no. 6, pp. 837-850, 2001.

[43] B. Mohan Kumar, S. J. George, and S. Chinnamani, "Diversity, structure and standing stock of wood in the homegardens of Kerala in peninsular India," Agroforestry Systems, vol. 25, no. 3, pp. 243-262, 1994. 
[44] M. Tolera, Woody species diversity of agricultural land scapes in Arsi Negelle District, Ethiopia: impact for biodiversity conservation [M.S. thesis], Wondo Genet College of Forestry and Natural Resource, Hawassa University, Awasa, Ethiopia, 2006.

[45] N. Gajaseni and J. Gajaseni, "Ecological rationalities of the traditional homegarden system in the Chao Phraya Basin, Thailand," Agroforestry Systems, vol. 46, no. 1, pp. 3-23, 1999. 

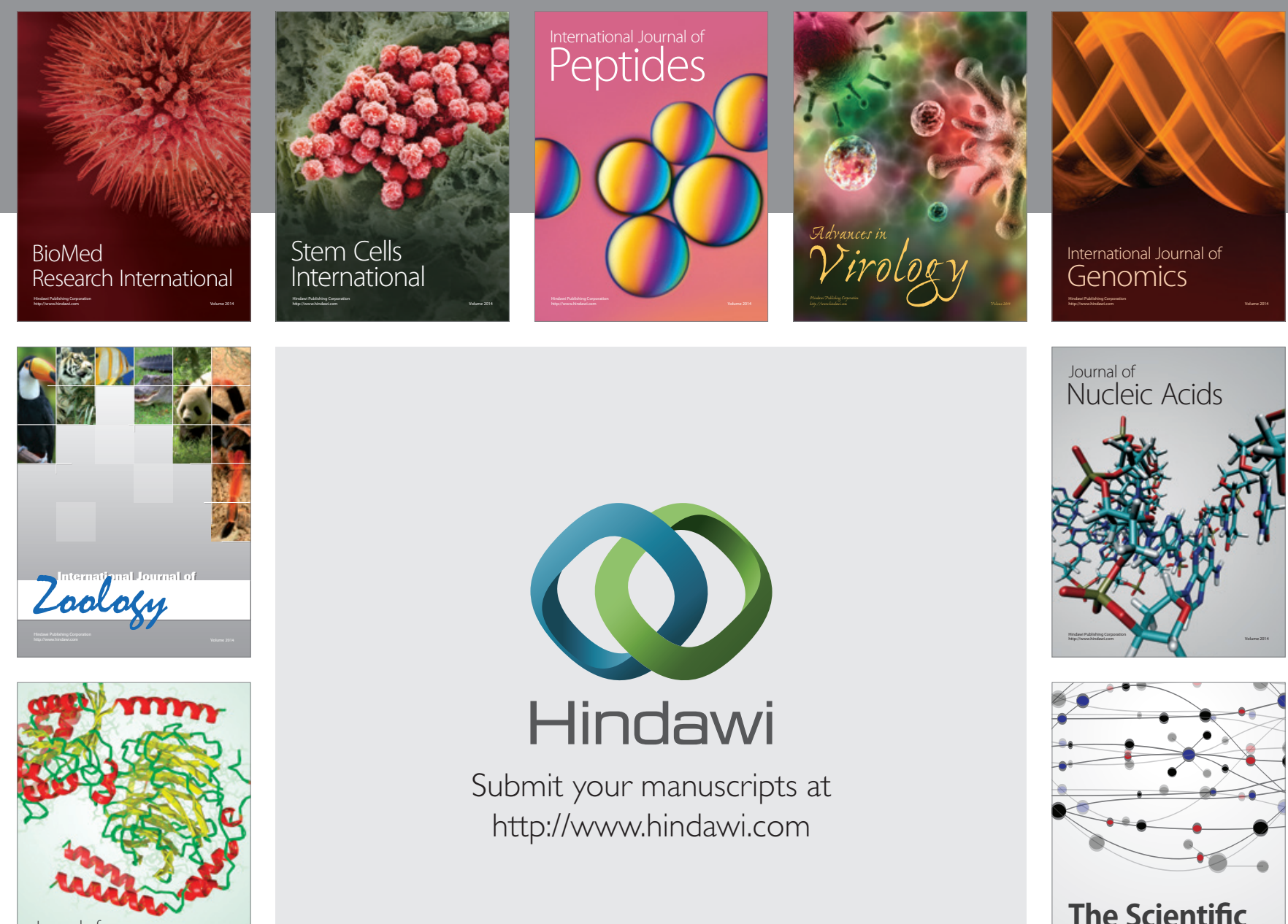

Submit your manuscripts at

http://www.hindawi.com

Journal of
Signal Transduction
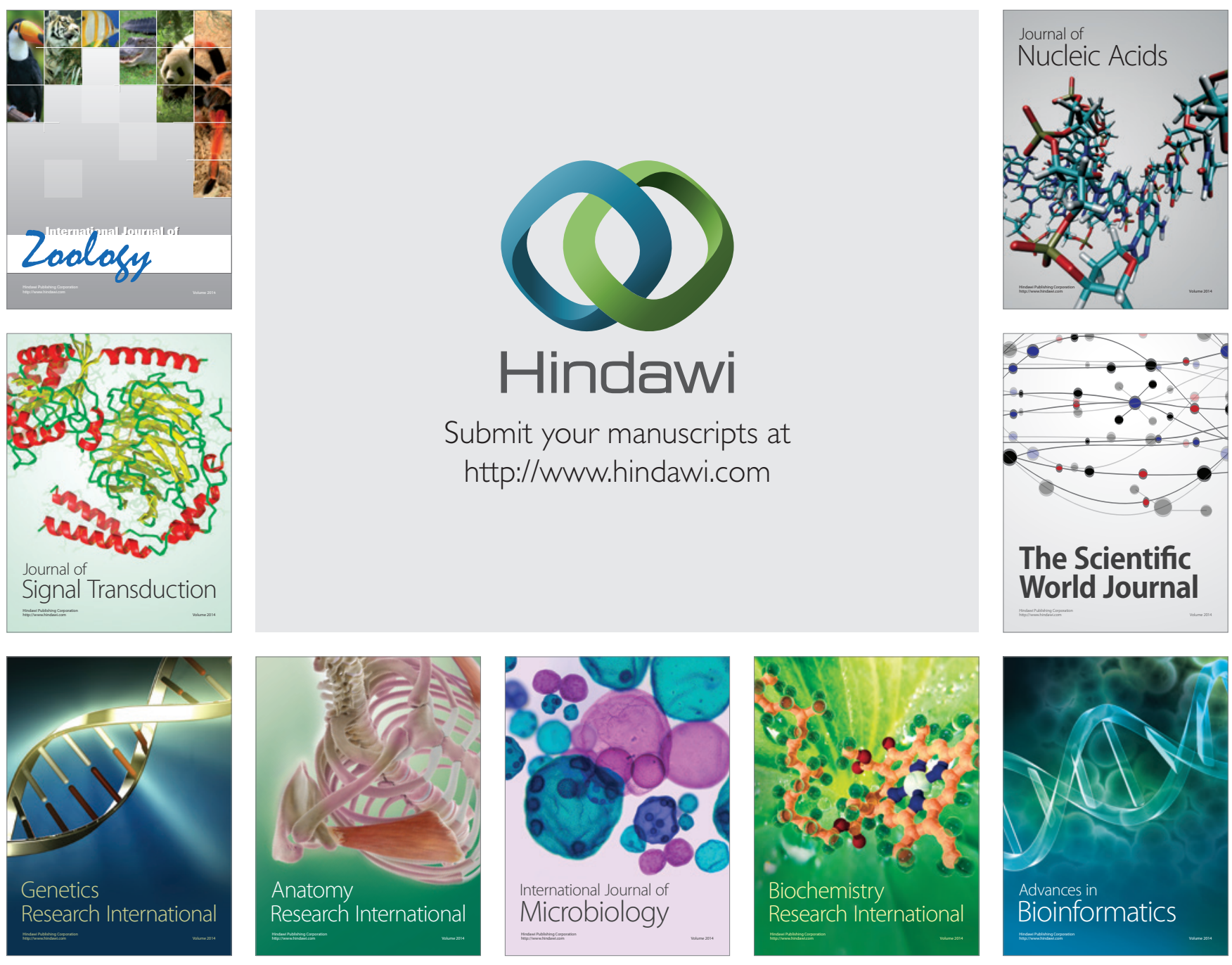

The Scientific World Journal
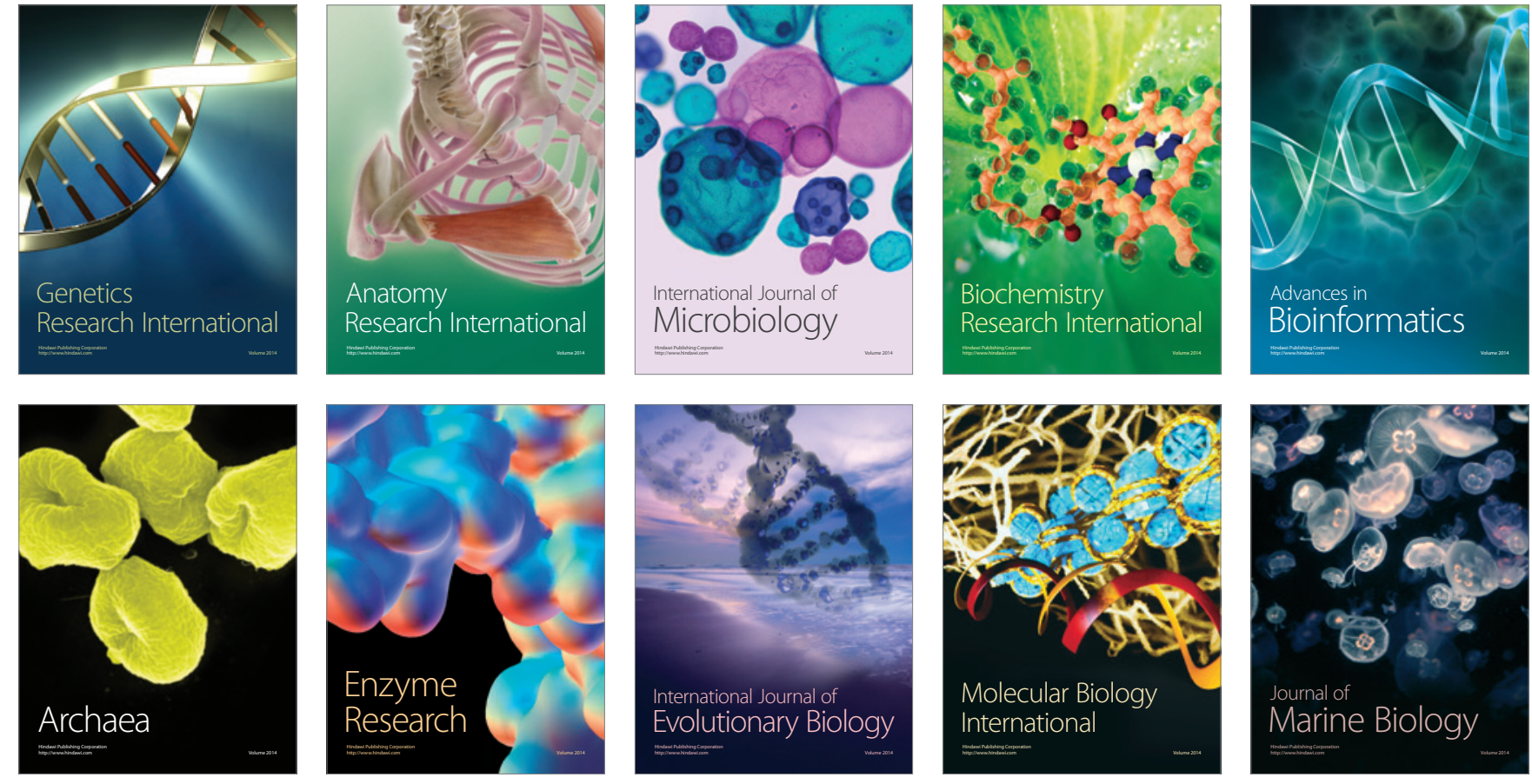